\title{
THE PACIFIC COAST SPECIES OF XYLOCOCCUS. (SCALE INSECTS).
}

\author{
Laura Florence.
}

In 1882, at the December meeting of the Société Entomologique de France, M. Victor Signoret (12) read a note from Dr. Franz Löw, calling attention to a recent publication by the Société Zoologique et Botanique de Vienne, of the description of a new Coccid for which he had created a new Genus Xylococcus.

The paper was published in 1882, under the title of "Eine neue Cocciden Art (Xylococcus filiferus)" (10). The insect was first discovered and sent to Dr. Löw in 1878, and he had it under observation from that time until the publication of his paper. He described in detail the first larval stage and the adult female, giving only a brief general description of an indefinite number of intervening stages. The remainder of the paper was occupied with notes on the life history, the position of the insects on the tree, and their method of penetrating into the lower layers of the bark.

There is no further reference to Xylococcus to be found until 1890, when in a paper entitled "How do Coccids Produce Cavities in Plants?" the author, Mr. W. M. Maskell (11), cited it as an example of a cavity-producing Coccid.

In 1898 a paper was published by H. G. Hubbard and Th. Pergande (6) on a new Coccid found on birch trees. Thus a second species of Xylococcus was recorded, the first to be found in America. This, having been found on birch trees in Lake Superior region, was named Xylococcus betule by Mr. Pergande. The paper was in two parts, the first by Mr. Hubbard was biological, the second by Mr. Pergande structural. In this paper were well pointed out the extremely interesting peculiarities, both structural and physiological, of these curious Coccids.

Both the above-mentioned species were listed by Professor T. D. A. Cockerell (1) in his "Tables for the Determination of the Genera of Coccida." He divided the sub-family Margarodince into two tribes, Margarodini and Xylococcini. In the latter he placed Xylococcus and two allied Genera Coleostoma and Callipappus. 
In the following year, 1900, Mr. E. M. Ehrhorn (5) published a short description of a third Xylococcus, which he found on a species of live oak in Stevens Creek Canyon, Santa Clara County, California, and named Xylococcus quercus.

In 1902 Professor Cockerell (2) included a brief description of the Genus in "A Contribution to the Classification of the Coccidce." Reference was made to the work of Löw and of Hubbard and Pergande, and the three known species listed.

In 1905, Mr. S. I. Kuwana (7) presented a description of a fourth species, Xylococcus matsumurce. Three years later a second Californian species was found on the Monterey Cypress trees near Pacific Grove, Monterey County, by Mr. G. A. Coleman (4). He made some short notes on the species, naming it Xylococcus macrocarpa. In the following year, 1909, Professor Cockerell (3) referred Xylococcus matsumurce to a new Genus Matsucoccus on the basis of the anal tube and the character of the last joint of the antenna.

Dr. Leonhard Lindinger (9) in his textbook on Scale Insects, published in 1912, gives a brief description of Xylococcus filiferus Löw. This has been taken from the original paper.

In 1914, Mr. S. I. Kuwana (8) described a scale insect from oak trees (Quercus serata) at Nishigahara, Tokyo, and other places in Japan. He named it Xylococcus napiformis n. sp., acknowledging Professor Cockerell's assistance in the determination of the species.

Of the two Californian species, Xylococcus macrocarpe Cole, and Xylococcus quercus Ehrh., each stage in the life history of the female and five stages in that of the male are described in detail in this paper. A new species from alder trees is described and I have called it Xylococcus alni $n$. sp. It was collected at Wenatchee, in the State of Washington, by Mr. E. J. Newcomer, of the Bureau of Entomology, who sent it to the Entomological Laboratory of Stanford University.

The distribution of this small group of Coccids presents some interesting features. They have been found on three continents, Europe, America, and Asia, and up to the present time each species has been recorded from one host plant only, $X y$ lococcus filiferus Löw, infesting linden trees in Lower Austria, $X y$ lococcus betulce Perg., infesting birch trees on the shores of Lake Superior, Xylococcus quercus Ehrh., and Xylococcus napiformis Kuw., infesting different species of oak trees, the 
former in California and the latter in Japan, Xylococcus macrocarpa Cole. infesting the Monterey Cypress, and Xylococcus alni $n$. sp., infesting alder trees. From this list it is seen that not only are those insects widely distributed geographically, but they are found on widely separated species of host plant. Nothing is known as to how the trees have become infested, or how the insects penetrate into the lower layers of the bark, where they are found surrounded by secretions of wax.

It is of peculiar interest that the Monterey Cypress, the host of Xylococcus macrocarpa Cole. (P1. XII, Fig. 1), is indigenous to a single area in California known as Del Monte Forest and extending for a few miles along the Pacific Coast in Monterey County. While collecting my specimens I found the insects on old and young trees alike. The infestation is not evenly distributed in the forest and the most heavily infested trees are easily distinguishable even at a distance by their black colour, due to the growth of a sooty mould fungus in the honey dew exuded by the insects.

Xylococcus quercus Ehrh. (P1. XII, Fig. 2) I have collected from oak trees (Quercus chrysolepis Liebmann) in Permenente Creek Canyon, Santa Clara County. There is a slight growth of sooty mould fungus on these infested trees also.

These insects infest the trunk and older branches of the trees, and their presence is indicated by numerous filaments of wax protruding from crevices in the bark and bearing drops of honey dew. There is great variety in the length and appearance of these filaments, some being straight, others wavy and almost spiral. This filament is a capillary tube issuing from the posterior end of the body from a chitinous organ called the anal tube, and formed by an extension of the outer walls of circles of chitinous spinnerets, that open into and surround the posterior end of the alimentary canal. Gross dissection shows the insects imbedded between the layers of the bark with their mouth-parts penetrating more deeply. They are surrounded by a homogeneous layer of wax that is given off from pores scattered over the body (P1. XIII, Fig. 1). The apodous stages of the insect are found in greatest number and in the case of Xylococcus macrocarpa Cole. the characteristic position is in groups varying in number (P1. XII, Fig. 3). Xylococcus quercus Ehrh. (P1. XIII, Fig. 2) and Xylococcus alni n. sp. (P1. XIII, Fig. 3), are seldom found in groups and their pits are more or less 
circular. In the case of the latter the presence of a pit seems to be indicated by a small swelling on the bark. Alongside the insects are found fragments of the wax covering and of the exuviae of previous instars.

The life histories seem to be identical with that of Xylococcus betulce Perg. as previously described. I have not succeeded, however, in finding a stage in the development of the male insect of macrocarpe, or quercus, or alni, corresponding to Pergande's second stage of betulce. The mouth-parts are very long, and when the larvæ first hatch can be seen coiled inside the insect (P1. XIII, Fig. 4). The young insects have well developed legs and move about actively before settling down. The male and the female are apparently not distinguishable in the first stage. After the first moult the female loses its legs and antennae and for three successive stages is apodous. Size, difference in number of the wax pores, and structural differences in the stigmatal tubes and anal tube serve to distinguish these stages. After the fourth moult the adult female issues. The insect has now regained the legs and antennæ, but lost the mouth parts (P1. XIII, Fig. 5). The insect may, without escaping from the exuvia of the fourth stage, rupture the end of the exuvia and present the posterior end of the body at the crevice in the bark for impregnation by the male, or she may escape from the pit and move about freely over the tree. In this case she finally settles under some projection of the bark and spins a cushion of flocculent wax beneath and a covering of powdery wax above her (P1. XII, Fig. 4). When the eggs are laid the abdomen becomes concave on the lower surface with the lateral margins revolute, so forming a pocket in which the eggs lie buried in wax until they hatch (P1. XIII, Fig. 6). After egg-laying the female dies, the anterior part of the body shrivelling up.

At the second moult the male insect becomes apodous, closely resembling the female of the third stage. In the fourth stage the legs and antennæ reappear and the mouth-parts and the chitinized anal tube are lost. The insect now emerges and wanders freely over the bark, finally settling under some raised part of the bark. It immediately begins to spin a long slender cylindrical cocoon of flocculent wax and within this the transformation to the pupal stage takes place. The pupæ have well 
developed free legs and antennæ (P1. XIII, Fig. 7), and the adult male (P1. XIII, Fig. 8) issues from the anterior end, escaping from the cocoon through a small circular aperture. The male is a beautiful insect with two abdominal brushes composed of brittle wax rods produced from groups of pores on the dorsal surface of the sixth and seventh abdominal segments. These brushes are longer than the insect.

The observations on the life history have been made from the trees where the material was collected and from branches brought into the laboratory and kept alive in water. The different stages were collected throughout the year. The males appear to issue during autumn and early winter and females with eggs are found during winter and spring. The larvæ from the eggs of one adult hatch over a considerable period of time. In the laboratory I have had them hatching successively from the same mass of eggs for over six weeks and in the field I found similar conditions.

The biology of these insects was admirably written up by Mr. H. G. Hubbard (6) in 1898, but a few more facts can now be added. In the adopous stages no external traces of the legs remain, but the antennæ are represented by microscopic chitinous discs bearing a few long and a few short hairs. The pigmented eye spots that disappear on boiling the specimens in $\mathrm{KOH}$, are situated near, but not contiguous to these antennal discs. The insects have ten pairs of spiracles, two pairs on the thorax and eight pairs on the abdomen. Those on the abdomen have large simple openings, and within the body form stigmatal tubes with an anterior constriction in which there are one or two rings of pores according to the instar. The thoracic spiracles have no stigmatal tubes. In the active stages their openings are marked by a small group of pores, and in the apodous stages these pores are wanting. In the successive apodous instars an increasing development of the anal tube is visible and this is one of the means of distinguishing them. Mr. Hubbard laid stress on the unusual life history of $X y$ lococcus betulce Perg. and pointed out many peculiarities of structure, showing parallels to them in several species of Coelostoma Mask. (Coelostomidia Ckll.) and of Margarodes Guilding. He suggested that these belonged to a hitherto unrecognized subfamily of the Coccidæ. Since that time Xylococcus and five other genera, Margarodes, Coelostoma, Callipappus, Kuwania 
and Matsucoccus have been placed in a new sub-family Margarodince. The common characters of the sub-family are, in the female, the absence of legs and antennæ in the intermediate stages and of mouth-parts in the adult, in the adult male, the presence of compound eyes. The following table will assist in the identification of the North American species of Xylococcus.

I. In first larval stage one median ventral pore.

In apodous stages anal tube without median circles of spinnerets.

II. In first larval stage more than one median ventral pore.

In apodous stages anal tube with median circles of spinnerets.

a. Anal tube with one median circle of spinnerets. Five median ventral

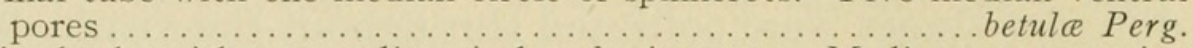

b. Anal tube with two median circles of spinnerets. Median pores varying from 2 to 4 ..........................................

c. Anal tube with three median circles of spinnerets. Median pores

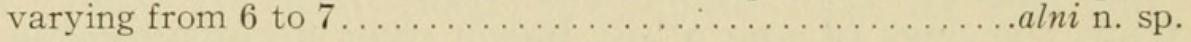

\section{Xylococcus macrocarpæ Cole.}

Eggs.-Length, .55 mm., diameter, .275 mm.; oval, highly polished; colour pale lemon yellow.

Larva, first stage.-Length about $.7 \mathrm{~mm}$, diameter about $.3 \mathrm{~mm}$. Color on hatching very pale yellow, later becoming tinged with red. Shape oblong-oval, sides sub-parallel narrowing a little posteriorly. Segments all well defined. Eyes black, situated on prominences lateral and posterior to antennæ (P1. XIV, fig. 1e). Antennæ six-jointed, short, stout; formula $6,1,2,5,(3,4)$; joint one stoutest, joints two to five approximately equal in diameter, last joint slender; all joints except three and four bearing hairs that increase in length towards apex; on joint five at base of exterior lateral edge a stout spine; on joint six a ring of four stout spines and a single spine on apex; a very long bristle at apex; a single pore on joint two (P1. XIV, fig. 1). Legs long and stout; tarsus longer than tibia; a ring of pores, one long hair and one short one on trochanter; digitules on tarsus fine unknobbed hairs, on claw knobbed hairs (P1. XIV, fig. 2). Rostrum large, situated about middle of body; sucking bristles very long. Anal tube rather short and broad, formed by an extension of the outer walls of a circle of chitinous spinnerets which surround and open into the posterior end of the alimentary canal. Spiracles, two pairs on thorax, eight pairs on abdomen; the former inconspicuous, the latter with well developed stigmatal tubes (P1. XIV, fig. 3). Body with hairs sparsely scattered over cephalic and thoracic areas, and on dorsal and ventral surfaces of abdomen in transverse rows, one on each segment; a pair of backward directed short lateral spines on each abdominal segment; on ventral surface of segment eight single long lateral bristles; pores of three types; a simple median ventral pore anterior to anal tube; compound lateral pores on each thoracic and first seven abdominal segments dorsally and ventrally; small pores as follows - a pair on cephalic area anterior to prothorax, a pair on the mesothorax, a pair on the metathorax, a pair 
on the eighth abdominal segment ventrally; dorsally two pairs on the last two abdominal segments; a single pore adjacent to each abdominal spiracle; in lateral view pores are short chitinous tubes (P1. XIV, figs. $4 \mathrm{a}$ and $4 \mathrm{~b})$.

Female, second, third and fourth stages.-Length from about $1.50 \mathrm{~mm}$. to about $4 \mathrm{~mm}$., breadth from about $.75 \mathrm{~mm}$. to about $2 \mathrm{~mm}$. Color dark red, posterior end of body brown owing to chitinous nature of last abdominal segments. Shape oblong-oval, bluntly rounded anteriorly; abdominal segments well marked, posterior segments being more compressed than in stage one. Eyes represented by small black pigment spots (disappearing on boiling in $\mathrm{KOH}$ ), situated near but not contiguous to antennal discs. Antennæ represented by microscopic chitinous discs bearing a few hairs varying in length and number. Legs wanting. Rostrum large, situated about middle of body. Anal tube in second stage with an increased number of spinnerets opening into it anteriorly, in third stage with two anterior circles of spinnerets, and in fourth stage with three anterior circles of spinnerets (P1. XIV, fig. 5). Two pairs of thoracic and eight pairs of abdominal spiracles; the former inconspicuous, the latter with well developed stigmatal tubes differing from those of first stage as illustrated (P1. XIV, figs. 3 and 6), and increasing in length in the successive instars; one row of pores in constriction in second and third and two rows in fourth stage. Integument smooth and shining, bearing a few microscopic hairs, and a few lateral abdominal spines. Pores of two types, (P1. XIV, fig. 7), compound type predominating, distributed irregularly on cephalic and lateral areas and arranged in transverse rows on segments two to seven of abdomen, simple type of pore interspersed among compound type. In successive stages hairs and spines increase in size and pores in number. Pores much more numerous in fourth than in preceding stages, arranged in bands on abdomen, and in all stages increasing in number posteriorly.

Female, fifth stage, adult.-The adult varies in length from $6 \mathrm{~mm}$. to $3 \mathrm{~mm}$. and in breadth from $3 \mathrm{~mm}$. to $1.50 \mathrm{~mm}$.; measurements of largest and smallest specimens found when moulting were respectively $5 \mathrm{~mm}$. x $2.50 \mathrm{~mm}$. and $3 \mathrm{~mm}$. x $1.50 \mathrm{~mm}$., specimens found with eggs $6 \mathrm{~mm}$. x $3 \mathrm{~mm}$. and $4 \mathrm{~mm}$. x $2 \mathrm{~mm}$. Color when living dark olive brown, with an indistinctly spotted appearance die to dark particles in the body fluid; on ventral surface revolute edges yellow; antennæ and legs yellow. Shape oblong-oval, broadest in thoracic region; segments all well defined. Eyes small, black, situated laterad to antennæ. Antennæ stout, nine-jointed; formula $1,3,2,(4,8,9), 5,(6,7)$; joint one longest and stoutest; joint three longer and more slender than two (division between joints two and three not always clearly defined); joints four, five, eight, and nine sub-equal in length and diameter; segments four to eight widening anteriorly where they bear a fringe of hairs; hairs increasing in length towards apex of antenna; last joint flattened at apex, longer at outer side, bearing a few spines as well as hairs; on joint two a small group of pores varying in number, sometimes absent (P1. XIV, fig. 8). Legs stout and rather short; tibia twice as long as tarsus; trochanter bearing two long hairs and a group of pores varying 
in number; digitules on tarsus and on claw fine unknobbed hairs (P1. XIV fig. 9). Rostrum wanting. Anal tube represented by an infolding of the body wall, not strongly chitinized. Two pairs of spiracles on thorax, eight pairs on abdomen; the former inconspicuous, the latter with well developed stigmatal tubes with two irregular rows of pores in constriction. Integument covered with short stiff hairs stoutest and most numerous anteriorly; a few short spines at posterior end; pores of two types scattered over body (P1. XIV, fig. 10); on abdomen arranged in indefinite bands; around vaginal opening, which is situated on ventral surface of seventh abdominal segment, they form a dense ring; smaller type of pore predominates.

Male, second stage.-Not found.

Male, third stage.-Length about $2.5 \mathrm{~mm}$., breadth about $1 \mathrm{~mm}$. Similar to stage three of female, but pores on body less numerous. Three posterior abdominal segments chitinised.

Male, fourth stage.-Length about $2.5 \mathrm{~mm}$., breadth about $.75 \mathrm{~mm}$. Color dark brownish red; legs light yellow, antennæ dark yellow. Shape oblong with sides sub-parallel; posterior end bluntly rounded; segments all well defined. Eyes large, black; situated laterad to antennæ. Antennæ rather short and stout; formula $1,(2,3,9), 8$, $(4,5,7), 6$; joint one stoutest, the others gradually diminishing in diameter; joints six to eight broadest anteriorly; nine longer at one side than the other; each joint bearing hairs increasing in length towards apex, terminal joint bearing a few spines as well as hairs; second joint bearing a group of pores varying in number (P1. XIV, fig. 11). Legs well developed, bearing many stout hairs especially on tibia; tibia almost two and a half times as long as tarsus; trochanter bearing two long hairs and a group of pores varying in number; digitules on tarsus and on claw fine unknobbed hairs (P1. XIV, fig. 12). Rostrum wanting. Anal tube wanting. Two pairs of spiracles on thorax, eight pairs on abdomen; the former inconspicuous, the latter with well developed stigmatal tubes with one row of pores in constriction. Integument covered with microscopic short, sharp hairs, stouter and more numerous on posterior segments; long, stout hairs and pores of one type (P1. XIV, fig. 13) thickly scattered over cephalic area; on thorax and abdomen pores arranged in bands segmentally; hairs increasing in number and size posteriorly.

Male, fifth stage.-Cast skin. Length about $1.75 \mathrm{~mm}$., breadth about $.7 \mathrm{~mm}$. Color pinkish red; antennæ dusky; legs dark yellow. shape oblong, sides sub-parallel, tapering slightly towards the posterior end; segments all well defined; wing pads reaching end of third abdominal segment. Antennæ long, nine-jointed; formula 9, 2, 3, (1, 8), $6,5,(4,7)$; all joints sub-equal in diameter; without hairs (occasionally a few short hairs present on first joint) (P1. XIV, fig. 14). Legs long and stout; tarsus about one-third length of tibia with vestigial claw; short hairs present on all joints except tarsus; a group of pores varying in number on trochanter (P1. XIV, fig. 15). Integument with hairs scattered over cephalic and thoracic areas; on abdomen arranged in 
transverse rows corresponding to segments; a few pores of same type as in stage four (P1. XIV, fig. 13) interspersed among abdominal hairs; a polygonal protuberance at end of body.

Male, sixth stage, adult.- "Length; body $2 \mathrm{~mm}$., width across thorax $.8 \mathrm{~mm}$., wings $3 \mathrm{~mm}$. long by $1 \mathrm{~mm}$. broad, expanse about $7 \mathrm{~mm}$.; color of head and thorax dark brown, abdomen yellow, with bands of brown above and below, wings cinereous; veins blackish; only one distinct branch to discoidal vein." (Coleman).

Eyes large, prominent and coarsely facetted. Antennæ ten-jointed, reaching middle of abdomen; joints one and two short and stout; joint three longest; remaining joints diminishing in length and diameter towards apex; all bearing numerous irregularly distributed fine hairs. Two pairs of wings; front pair cinereous with irregularly reticulate surface; discoidal vein with one distinct branch (tending to disappear in mounted specimens); hind wings very small, bearing three stout hooks at apex (P1. XIV, fig. 16). Legs long, bearing numerous hairs particularly on tibia; tibia nearly twice as long as femur and nearly four times as long as tarsus; tarsus two-jointed, first joint short; digitules fine unknobbed hairs (P1. XIV, fig. 17). Short fine hairs scattered over integument; on dorsal surface of sixth abdominal segment two groups, each of fifteen pores, on the seventh segment two groups, each of twelve pores (it is from these pores that the abdominal brush issues); style short and conical, with a broad base; sexual organ as long as abdomen and finely annulated (annulations showing under high power of microscope) (P1. XIV, fig. 18).

\section{Xylococcus quercus Ehrh.}

Eggs.-Length .65 mm., diameter $.34 \mathrm{~mm}$; oval, highly polished; color varying from pale orange yellow to light red.

Larva, first stage.-Length varying from $.65 \mathrm{~mm}$. to $.75 \mathrm{~mm}$, diameter from $.35 \mathrm{~mm}$. to $.40 \mathrm{~mm}$. Color orange red. Shape broadly oval; segments all well defined. Eyes black, situated on prominences posterior and laterad to antennæ (P1. XIV, fig. 19e). Antennæ short, stout; six-jointed; formula $6,1,5,2,4,3$; joint one stoutest; remaining joints approximately equal in diameter; joints three and four without hairs; hairs on joints one, two, five and six increasing in length towards apex; on joint five at base of exterior lateral edge a stout spine; on joint six a ring of four stout spines near the base and a single spine on the apex, a very long bristle at apex; a single pore on joint two (P1. XIV, fig. 19). Legs long and stout; tarsus longer than tibia; a ring of pores and one long hair on trochanter; a few hairs on tibia and tarsus; digitules on tarsus fine unknobbed hairs, on claw knobbed hairs (Pl. XV, fig. 1). Rostrum large, situated about middle of body; sucking bristles very long. Anal tube protruding from body, being an extension of the outer walls of two groups of chitinous spinnerets that open into the posterior end of the alimentary canal. Two pairs of spiracles on thorax, eight pairs on abdomen; the former inconspicuous; the latter with well developed stigmatal tubes (P1. XIV, fig. 3). Integument smooth and 
shining, after clearing in $\mathrm{KOH}$ seen to be covered with microscopic pits, increasing in size posteriorly; hairs scattered over cephalic and thoracic areas, and on dorsal and ventral surfaces of abdomen in transverse rows, one on each segment; a pair of backward directed lateral spines increasing in size posteriorly on each abdominal segment; on ventral surface of segment eight single long lateral bristles; pores of three types - a median ventral row of large pores anterior to anal tube and varying in number from two to four; medium-sized lateral pores on each abdominal segment dorsally and ventrally; small pores as follows: a pair on the mesothorax, a pair on the metathorax, two pairs on each segment of the abdomen ventrally; dorsally a pair on the metathorax, two pairs on the first seven abdominal segments and three pairs on the eighth; in lateral view pores resemble short chitinous tubes (P1. XIV, figs. 20a and 20b).

Female, second, third and fourth stages.-Length from about $1 \mathrm{~mm}$. to $4 \mathrm{~mm}$., breadth from about $1.75 \mathrm{~mm}$. to about $3 \mathrm{~mm}$. Color deep red, posterior end of body brown owing to chitinous nature of last abdominal segments. Shape sub-spherical; segments not clearly defined; posterior segments more compressed than in stage one. Eyes represented by small black pigment spots (disappearing on boiling in $\mathrm{KOH}$ ), situated near, but not contiguous to antennal discs. Antennæ represented by microscopic chitinous discs bearing a few hairs varying in length and number. Legs wanting. Rostrum large, situated about middle of body. Anal tube in second stage with an increased number of spinnerets opening into it anteriorly and a sparse median transverse circle of spinnerets, in third stage with three anterior circles of spinnerets and one median transverse circle, in fourth stage with five anterior circles of spinnerets and two median transverse circles (Pl. XIV, fig. 21). Two pairs of thoracic and eight pairs of abdominal spiracles; the former inconspicuous, the latter with well developed stigmatal tubes differing from those of first stage as illustrated (P1. XIV, figs. 3 and 6), and increasing in length in the successive instars; one row of pores in constriction in second and third stages and two rows in fourth stage. Integument smooth and shining; after clearing in $\mathrm{KOH}$ seen to be covered with microscopic pits, increasing in size posteriorly; lateral abdominal spines increasing in size posteriorly; a few hairs scattered over body. Pores of two types (P1. XV, fig. 2)-large pores scattered on anterior cephalic area; a few small lateral pores on thorax, large and small pores arranged in transverse rows on segments one to seven of abdomen. In the successive stages hairs and spines increase in size and pores in number. Pores much more numerous in fourth than in preceding stages, and in all stages increasing in number posteriorly.

Female, fifth stage, adult.-Length varying from $5.5 \mathrm{~mm}$. to $4 \mathrm{~mm}$., breadth from $4 \mathrm{~mm}$. to $3 \mathrm{~mm}$. Color when living dull brownish red; antennæ and legs brighter. Shape oval, broadest in thoracic region, broadly rounded at posterior end; segments all well defined. Eyes small, black; situated laterad to antennæ. Antennæ long, stout, ninejointed; formula $1,9,2,3,6,4,7,(5,8)$; joints one to four stoutest; 
joints five to eight sub-equal; joint nine slender; on joints one and two hairs scattered, on joints three to eight arranged in a fringe at anterior edge and increasing in length towards apex of antenna; terminal joint bearing a ring of four stout spines, two long hairs and a number of shorter hairs; on joint two a group of pores varying in number (P1. XV, fig. 3). Legs very stout; tibia twice as long as tarsus; trochanter bearing two long, a number of shorter hairs and a group of pores varying in number; digitules on tarsus and on claw fine unknobbed hairs (P1. XV, fig. 4). Rostrum wanting. Anal tube represented by an infolding of body wall, not strongly chitinised. Two pairs of spiracles on thorax and eight pairs on abdomen; the former inconspicuous, the latter with well developed stigmatal tubes bearing two rows of pores in constriction. Integument covered with short hairs, most numerous on dorsal and lateral areas, and on ventral surface of abdomen arranged in transverse rows segmentally; pores of two types (P1. XV, fig. 5) thickly scattered over cephalic and thoracic areas, and on abdomen arranged in transverse bands segmentally, the bands on dorsal surface being broader and more dense than those on ventral surface; around vaginal opening pores become more numerous; smaller type of pore predominates.

Male, second stage.-Not found.

Male, third stage.-Similar to stage three of female, but longer and more slender. Pores on body less numerous than on stage three of female; six posterior abdominal segments strongly chitinised.

Male, fourth stage.-Length $2 \mathrm{~mm}$., breadth $1.3 \mathrm{~mm}$. Color deep red; legs and antennæ yellow. Shape oblong, broadest in thoracic region; head and thorax together longer than abdomen; segments all well defined. Eyes small, black, situated laterad to antennæ. Antennæ rather short and stout; nine-jointed; formula $1,2,9,3,7,(4,8), 6,5$; joints one to three stoutest; joints four to eight sub-equal; joint nine slender; hairs on each joint increasing in length towards apex, on joints three to eight forming a fringe at anterior extremity; a few spines as well as hairs borne on terminal segment; on joint two a group of pores varying in number (P1. XV, fig. 6). Legs well developed, bearing many stout hairs; tibia twice as long as tarsus; trochanter with one long hair and a group of pores varying in number; digitules on tarsus and on claw fine unknobbed hairs (P1. XV, fig. 7). 'Rostrum wanting. Anal tube wanting. Two pairs of spiracles on thorax and eight pairs on abdomen; the former inconspicuous, the latter with well developed stigmatal tubes with one row of pores in constriction. Integument covered with microscopic short, sharp hairs, stouter and more numerous on posterior segments; long stout hairs and pores of one type (P1. XV, fig. 8) thickly scattered over cephalic area; on thorax and abdomen these are less numerous and are arranged in bands segmentally; hairs increasing in number and size posteriorly.

Male, fifth stage, pupa.-Cast skin. Length about $2 \mathrm{~mm}$., breadth about $1 \mathrm{~mm}$. Color of abdomen deep red; thorax, legs and antennæ yellow; in dried specimens pigment is broken up, causing a spotted appearance (P1. XIII, fig. 7). Shape rather broad and short; head and 
thorax together longer than abdomen; wing pads broad, reaching beyond hind coxæ. Antennæ long, nine-jointed; formula 1, 3, (4, 5), 9, 6, 2, 7, 8 ; all joints sub-equal in diameter and distally annulated with white; without hairs (occasionally a few short ones on joint one) (P1. XV, fig. 9). Legs long and stout, tarsus little more than one-third length of tibia with vestigial claw; short hairs present on all joints except tarsus; trochanter bearing a group of pores varying in number (P1. XV, fig. 10). Integument with hairs scattered over cephalic and thoracic areas; on abdomen arranged segmentally in transverse rows; a few pores of same type as in stage four (P1. XV, fig. 8) interspersed among abdominal hairs; a polygonal protuberance at end of body.

Male, sixth stage, adult.- "About $3 \mathrm{~mm}$. long and $1.5 \mathrm{~mm}$. broad, slightly pubescent. Color of abdomen reddish brown. Mesothorax black, with four raised knobs. Front part of head black, eyes very prominent, strongly facetted, black. Legs and antennæ black and very hairy. Ventral surface of abdomen dark brown, segmentation distinct. Mesosternum black, a small black line on prosternum, and an irregular black patch on metasternum. Abdominal brushes with long stout glassy bristles about $6 \mathrm{~mm}$. long. Style short, stout and conical. Antennæ ten-jointed, very hairy, reaching beyond end of abdomen. Joint two shortest, joints three and ten a little longer, and the other joints sub-equal. Each joint with numerous hairs. Wings large, about $3 \mathrm{~mm}$. long and $1 \mathrm{~mm}$. broad, expanse about $7 \mathrm{~mm}$., smoky, slightly pubescent, with the costal space blackish-brown. Halteres resembling small wings with several hooks. Legs long and very hairy. Femur much shorter than tibia. Tibia about four times as long as tarsus. Digitules fine hairs. Claw long and slender and well curved. Digitules short club-shaped hairs." (Ehrhorn).

\section{Xylococcus alni n. sp.}

No measurements of this insect were taken, because only dried specimens were at hand.

Eggs.-Color deep lemon yellow.

Larva, first stage.-Color orange red. Shape broadly oval, segments all well defined. Eyes black; situated on prominences lateral and posterior to antennæ (P1. XV, fig. 11e). Antennæ short, stout, sixjointed; formula $6,2,1,(4,5), 3$; joints one and two stoutest; remaining joints approximately equal in diameter; joints three and four without hairs; hairs on joints one, two, five, and six increasing in length towards apex of antenna; on joint five at base of exterior lateral edge a stout spine; on joint six a ring of four stout spines near the base and a single spine on apex; a very long bristle at apex; a single pore on joint two (P1. XV, fig. 11). Legs long and stout; tarsus longer than tibia; a ring of pores and one long hair on trochanter; a few hairs on tibia and tarsus; digitules on tarsus fine unknobbed hairs, on claw knobbed hairs (P1. XV, fig. 12). Rostrum large; situated about middle of body; sucking bristles very long. Anal tube large; formed by an extension of the outer walls of a circle of chitinous spinnerets which surround and open 
into the posterior end of the alimentary canal. Two pairs of spiracles on thorax and eight pairs on abdomen; the former inconspicuous, the latter with well developed stigmatal tubes (P1. XIV, fig. 3). Integument smooth, after clearing in $\mathrm{KOH}$ seen to be covered with microscopic pits increasing in size posteriorly; hairs sparsely scattered over cephalic and thoracic areas, arranged in transverse rows segmentally on dorsal and ventral surfaces of abdomen; a pair of backward directed lateral spines increasing in size posteriorly on each abdominal segment; on ventral surface of segment eight single lateral long bristles; pores of four types - type I, a median ventral row of large pores anterior to anal tube and varying in number from six to seven; type II, medium-sized lateral pores on each abdominal segment dorsally and ventrally; type III, small pores as follows, a pair on the mesothorax and a pair on the metathorax ventrally, dorsally a pair on the metathorax, a pair on first abdominal segment, and two pairs on the succeeding segments; type IV, very small pores on dorsal surface of segments two to eight of abdomen (P1. XV, figs. $13 \mathrm{a}$ and $13 \mathrm{~b}$ ).

Female, second, third and fourth stages.-Color red, posterior end of body brown, owing to chitinous nature of last abdominal segments. Shape ovoid, broadest in thoracic region, bluntly rounded anteriorly; abdominal segments well marked, posterior segments more compressed than in stage one. Eyes represented by small black pigment spots (disappearing on boiling in $\mathrm{KOH}$ ), situated near, but not contiguous to antennal discs. Antennæ represented by microscopic chitinous discs bearing a few hairs varying in length and number. Legs wanting. Rostrum large, situated about middle of body. Anal tube in second stage with additional anterior spinnerets and a few median spinnerets, in third stage with an increased number of spinnerets, in fourth stage with two anterior circles of spinnerets and three median transverse circles of spinnerets (P1. XV, fig. 14). Two pairs of thoracic and eight pairs of abdominal spiracles, the former inconspicuous, the latter with well developed stigmatal tubes, differing from those of first stage as illustrated (P1. XIV, figs. 3 and 6), and increasing in length in the successive instars, one row of pores in constriction in second and third stages and two irregular rows in fourth stage. Integument smooth, after clearing in $\mathrm{KOH}$ seen to be covered with microscopic pits increasing in size posteriorly; a few microscopic hairs on lateral areas; a few small lateral spines posteriorly. Pores of two types (P1. XV, fig. 15); large pores scattered sparsely on cephalic and thoracic areas; on abdomen large and small pores arranged in transverse rows segmentally; small lateral pores scattered on abdomen. In the successive stages hairs and spines increase in size and pores in number. Pores much more numerous in fourth than in preceding stages and arranged in bands segmentally on abdomen. In all stages pores increase in number posteriorly.

Female, fifth stage, adult.-Color dark red. Shape oblong-oval; segments all well defined. Eyes small, black, laterad to antennæ. Antennæ long and stout; nine-jointed; formula 1, 9, 2, (3, 7), 5, (4, 6, 8); joints one to three stoutest; joints four to eight sub-equal; joint nine 
slender; hairs on joints one and two irregular, on joints three to eight distributed in a fringe on widest anterior part of segment; on terminal joint hairs and spines; hairs increasing in length towards apex of antenna; on joint two a group of six pores (P1. XV, fig. 16). Legs stout and short; tibia more than twice as long as tarsus; trochanter. with two long hairs and a group of pores varying in number; hairs on all parts, most numerous on tibia; digitules on tarsus and on claw fine unknobbed hairs (P1. XV, fig. 17). Rostrum wanting. Anal tube represented by an infolding of the body wall and not strongly chitinised. Two pairs of spiracles on thorax and eight pairs on abdomen; the former inconspicuous, the latter with well developed stigmatal tubes with two rows of pores in constriction. Integument covered with hairs, becoming more numerous posteriorly; pores of two types (P1. XV, fig. 18) densely scattered over cephalic region and less densely over thorax and abdomen; smaller type of pore predominating.

Male, second stage.-Not found.

Male, third stage.- Similar to stage three of female; pores less numerous than in stage three of female; six posterior abdominal segments strongly chitinised.

The fourth, fifth and six stages of the male of this species have not yet been found.

This study has been made in the Entomological Laboratory. of Stanford University, and there, are preserved the type specimens of Xylococcus alni $n$. sp.

The drawings on Plate XIII and figures three and six on Plate XIV are the work of Mr. W. S. Atkinson. The other drawings were made with a camera lucida, and an oil immersion was used in studying the structure of the wax pores.

\section{BIBLIOGRAPHY.}

1. Cockerell, T. D. A. "Tables for the Determination of Coccidæ." Can. Ent., XXXI, p. 275 (1899).

2. Cockerell T. D. A. "A Contribution to the Classification of the Coccidæ." The Entom., XXXV, p. 259 (1902).

3. Cockerell, T. D. A. "The Japanese Coccidæ." Can. Ent., XLI, p. 55 (1909).

4. Coleman, George A. "Coccidæ of the Coniferæ. Supplement No. 1, Description of two new species." Jn. N. Y. Ent. Soc., XVI, p. 198 (1908).

5. Ehrhorn, Edw. M. "New Coccidæ from California." Can. Ent., XXXII, p. $311(1900)$.

6. Hubbard, H. G., and Pergande, Th. "A new Coccid on Birch." Bull. 18, n. s., Dep. Ag., p. 13 (1898).

7. Kuwana, S. I. "Xylococcus matsumuræ n. sp." Insect World, IX, 3, March, (1905).

8. Kuwana, S. I. “Coccidæ of Japan." Pomona Journ. Ent. \& Zoo., VI, p. 1, (1914).

9. Lindinger, Leonhard. "Die Schildläuse (Coccidae)." Hamburg, (1912).

10. Loew, Franz. "Eine neue Cocciden-Art (Xylococcus filiferus)." Verh. z. b. Ges., Wien, p. 271, (1882).

11. Maskell, W. M. "How do Coccids produce Cavities in Plants?" Ent. Mon. Mag., XXVI, p. 278, (1890).

12. Signoret, Victor. "Xylococcus filiferus n. sp." Bull. Soc. Ent. Fr., (6), II, p. CLXXXV (1882). 


\section{EXPLANATION OF PLATES.}

\section{Plate XII.}

No. 1. Xylococcus macrocarpa Cole. on Monterey Cypress, showing filaments.

No. 2. Xylococcus quercus Ehrh. on Quercus chrysolepis, showing filaments.

No. 3. Position of Xylococcus macrocarpa Cole. under bark.

No. 4. Xylococcus quercus Ehrh., adult females.

\section{Plate XIII.}

Fig. 1. Xylococcus quercus Ehrh., fourth stage of female.

Fig. 2. Position of Xylococcus quercus Ehrh., bark removed.

Fig. 3. Pits of Xylococcus alni $\mathrm{n}$. sp., insects removed. a, dorsal; b, ventral.

Fig. 4. Xylococcus quercus Ehrh., first larval stage.

Fig. 5. Xylococcus macrocarpa Cole., adult female, a dorsal; b, ventral.

Fig. 6. Xylococcus quercus Ehrh., adult female showing egg-mass.

Fig. 7. Xylococcus quercus Ehrh., pupa of male insect.

Fig. 8. Xylococcus macrocarpa Cole., adult male.

\section{Plate XIV.}

\section{Xylococcus macrocarpe Cole.}

Fig. 1. Antenna of first larval stage; e, eye.

Fig. 2. Leg of first larval stage.

Fig. 3. Abdominal stigmatal tube of first larval stage.

Fig. 4. Posterior segments of abdomen of first larval stage, showing spines, pores, anal tube, and stigmatal tubes; $a$, dorsal; $b$, ventral.

Fig. 5. Anal tube of fourth stage of female; a, alimentary canal; b, anterior spinnerets; dd, posterior stigmatal tubes.

Fig. 6. Abdominal stigmatal tube of fourth stage of female, showing two rows of pores in constriction.

Fig. 7. Body pores of apodous stages of female.

Fig. 8. Antenna of adult female.

Fig. 9. Leg of adult female.

Fig. 10. Body pores of adult female.

Fig. 11. Antenna of fourth stage male.

Fig. 12. Leg of fourth stage male.

Fig. 13. Body pore of fourth and fifth stages of male.

Fig. 14. Antenna of pupa of male.

Fig. 15. Leg of pupa of male.

Fig. 16. Hind wing of adult male.

Fig. 17. Leg of adult male.

Fig. 18. Posterior end of body of adult male; a1, groups of pores; a2, pore enlarged; b, sexual organ.

\section{Xylococcus quercus Ehrh.}

Fig. 19. Antenna of first larval stage; e, eye.

Fig. 20. Posterior segments of abdomen of first larval stage, showing spines, pores, anal tube, and stigmatal tubes; a, dorsal; b, ventral.

Fig. 21. Anal tube of fourth stage of female; a, alimentary canal; b, anterior spinnerets; c, median spinnerets; dd, posterior stigmatal tubes. 
Plate XV.

Xylococcus quercus Ehrh.

Fig. 1. Leg of first larval stage.

Fig. 2. Body pores of apodous stages of female.

Fig. 3. Antenna of adult female.

Fig. 4. Leg of adult female.

Fig. 5. Body pores of adult female.

Fig. 6. Antenna of fourth stage male.

Fig. 7. Leg of fourth stage male.

Fig. 8. Body pore of fourth and fifth stages of male.

Fig. 9. Antenna of pupa of male.

Fig. 10. Leg of pupa of male.

Xylococcus alni $\mathrm{n} . \mathrm{sp}$.

Fig. 11. Antenna of first larval stage; e, eye.

Fig. 12. Leg of first larval stage.

Fig. 13. Posterior segments of abdomen of first larval stage, showing spines, pores, anal tube, and stigmatal tubes; a dorsal; b, ventral.

Fig. 14. Anal tube of fourth stage of female; a, alimentary canal; b, anterior spinnerets; c, median spinnerets; dd, posterior stigmatal tubes.

Fig. 15. Body pores of apodous stages of female.

Fig. 16. Antenna of adult female.

Fig. 17. Leg of adult female.

Fig. 18. Body pores of adult female. 


\section{$2 \mathrm{BHL}$ Biodiversity Heritage Library}

Florence, Laura. 1917. "The Pacific Coast Species of Xylococcus. (Scale Insects)." Annals of the Entomological Society of America 10, 147-162. https://doi.org/10.1093/aesa/10.2.147.

View This Item Online: https://www.biodiversitylibrary.org/item/43648

DOI: https://doi.org/10.1093/aesa/10.2.147

Permalink: https://www.biodiversitylibrary.org/partpdf/193658

\section{Holding Institution}

Smithsonian Libraries

\section{Sponsored by}

Smithsonian

\section{Copyright \& Reuse}

Copyright Status: NOT_IN_COPYRIGHT

This document was created from content at the Biodiversity Heritage Library, the world's largest open access digital library for biodiversity literature and archives. Visit BHL at https://www.biodiversitylibrary.org. 